\title{
Peningkatan Hasil Belajar Peserta Didik pada Mata Pelajaran Ekonomi Melalui Model Pembelajaran Artikulasi Kelas XI di MA Nurul Huda Sukaraja
}

\author{
Mursilah \\ STKIP Nurul Huda OKU Timur \\ E-mail: buk_mursilah@yahoo.co.id
}

\begin{abstract}
Abstrak: Pendidikan merupakan hal yang sangat penting bagi setiap manusia, karena melalui pendidikan manusia akan memperoleh pengalaman yang bermanfaat. Pendidikan juga dapat mengembangkan potensi-potensi serta keterampilan-keterampilan yang dimiliki setiap individu untuk menghadapi perubahan jaman yang semakin berkembang. Sehingga setiap manusia berhak memperoleh pendidikan. Penelitian ini bertujuan untuk meningkatkan hasil belajar peserta didik dalam mata pelajaran Ekonomi melalui penerapan model pembelajaran artikulasi pada peserta didik MA Nurul Huda Sukaraja. Penelitian ini merupakan penelitian tindakan kelas yang dilakukan secara kolaboratif antara guru dan peneliti. Penelitian dilaksanakan dalam dua siklus yaitu siklus I dan siklus II. Instrumen dalam penelitian ini berupa lembar observasi peserta didik, lembar observasi guru, dan tes tertulis. Pengumpulan data dilakukan dengan cara observasi dan tes tertulis. Hasil penelitian menunjukkan siklus I hasil observasi peserta didik sebesar $87,34 \%$ dan guru sebesar $92,16 \%$ dan hasil belajar peserta didik pada siklus I sebesar $73,16 \%$ dengan peserta didik yang tuntas 20 orang dan yang tidak tuntas 10 peserta didik. Siklus II hasil observasi peseta didik sebesar 97,58 dan guru sebesar 100\% dan hasil belajar peserta didik pada siklus II sebesar $89,66 \%$ dengan peserta didik yang tuntas 29 orang dan yang tidak tuntas 1 peserta didik.
\end{abstract}

Kata Kunci: Hasil belajar peserta didik, Model Artikulasi.

UTILITY: Jurnal IImiah Pendidikan dan Ekonomi

Website : http://journal.stkipnurulhuda.ac.id/index.php/utility

Permalink: https://journal.stkipnurulhuda.ac.id/index.php/utility/article/view/281

How to cite (APA): Mursilah, M. (2018, February 1). Peningkatan Hasil Belajar Peserta Didik pada Mata Pelajaran Ekonomi Melalui Model Pembelajaran Artikulasi Kelas XI di MA Nurul Huda Sukaraja. UTILITY: Jurnal IImiah Pendidikan Dan Ekonomi, 2(1), 19-29.

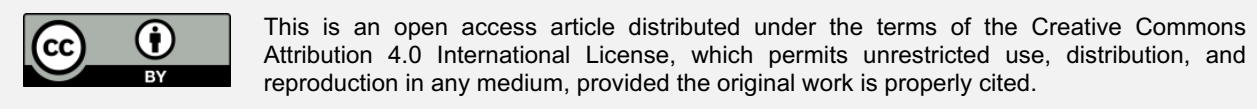

\section{PENDAHULUAN}

Pendidikan merupakan hal yang sangat penting bagi setiap manusia, karena melalui pendidikan manusia akan memoperoleh pengalaman yang 
bermanfaat. Pendidikan juga dapat mengembangkan potensi-potensi serta keterampilan- keterampilan yang dimiliki setiap individu untuk menghadapi perubahan jaman yang semakin berkembang. Melalui pendidikan manusia memperoleh pengalaman yang berguna bagi dirinya, keluarga, dan masyarakat. Peningkatan mutu pendidikan perlu dilakukan agar kualitas manusia Indonesia mampu bersaing dalam menghadapi tantangan global. Di dalam dunia pendidikan tingkat kemampuan peserta didik dilihat dari hasil belajar.

Menurut Suprijono (2012: 5) hasil belajar adalah pola-pola perbuatan, nilai-nilai, pengertian-pengertian, sikap-sikap, apresiasi dan keterampilan. Hasil belajar menurut Purwanto (2009: 46) adalah perubahan perilaku disebabkan karena seseorang telah mencapai penguasaan atas sejumlah bahan yang diberikan dalam proses pembelajaran. Berdasarkan pendapat tersebut dapat disimpulkan hasil belajar adalah tingkat kemampuan peserta didik setelah mengalami proses belajar dari suatu materi.

Menurut Trianto (2009: 5), masalah utama dalam pembelajaran pada pendidikan formal adalah masih rendahnya daya serap peserta didik. Hal ini tampak dari rerata hasil belajar peserta didik yang senantiasa masih sangat rendah. Rendahnya hasil belajar tersebut disebabkan karena peserta didik kurang semangat dalam pembelajaran, rendahnya pemahaman peserta didik terhadap materi yang disampaikan oleh guru, dan peserta didik pasif dalam proses pembelajaran. Akibatnya saat dilakukan evaluasi hasil belajar, nilai peserta didik rendah.

Untuk mangatasi masalah tersebut, maka guru harus berusaha menerapkan model-model variatif tertentu untuk membangkitkan semangat belajar peserta didik supaya konsentrasi, partisipasi , dan hasil belajar peserta didik lebih baik lagi. Salah satu model yang dapat dilakukan adalah model pembelajaran artikulasi. Model Artikulasi ini memberikan kesempatan peserta didik untuk lebih aktif dalam pembelajaran karena saat peserta didik menerima penjelasan dari Guru diwajibkan membuat resume atau catatan singkat dari apa yang diterangkan Guru tersebut dan kemudian setelah peserta didik menerima penjelasan Guru, peserta didik dituntut untuk mampu menerangkan kembali kepada teman sendiri dikelas sehingga peserta didik akan mengurangi rasa takut apabila bertanya kepada teman sendiri dan kapasitas guru sebagai motivator dalam pembelajaran ini. 
Berdasarkan data hasil ulangan harian untuk mata pelajaran Ekonomi di kelas XI MA Nurul Huda Sukaraja daftar nilai peserta didik masih banyak yang belum mencapai nilai standar KKM yang berlaku yaitu sebesar 73, yakni dari jumlah peserta didik 30 orang yang tuntas sebanyak 13 orang atau 43,33\% dan peserta didik yang belum mencapai ketuntasan 17 orang atau 56,67\% sementara kriteria untuk ketuntasan mata pelajaran Ekonomi adalah 73 (KKM) serta target yang ingin peneliti capai dalam penelitian ini sebesar 95\%.

Dalam proses pembelajaran mata pelajaran Ekonomi dengan menggunakan model pembelajaran artikulasi pada kelas XI MA Nurul Huda Sukaraja diharapkan dapat meningkatkan hasil belajar peserta didik, serta peserta didik mampu mengembangkan materi yang telah disampaikan oleh Guru. Kemudian peserta didik dapat menyimpulkan materi pelajaran yang telah diterima dari Guru maupun pasangannya/ kelompok lain.

\section{METODE}

Penelitian ini merupakan Penelitian Tindakan Kelas (PTK). Menurut Kunandar (2010: 46) PTK adalah suatu kegiatan ilmiah yang dialakukan oleh guru di kelasnya sendiri dengan jalan merancang, melaksanakan, mengamati, dan merefleksi tindakan melalui beberapa siklus secara kolaboratif dan partisipatif yang bertujuan untuk memperbaiki atau meningkatkan mutu proses pembelajaran di kelasnya.

Dalam pelaksanaan penelitian, peneliti berkolaborasi dengan teman sejawat yang meliputi: Perencanaan Tindakan, pelaksanaan tindakan, pengamatan dan refleksi. Adapun desain penelitian yang dipakai penelitian ini adalah model sekema spiral dari Hopkin (Dalam Jurnal Ilmiah Progressif, 2009: 50) dengan menggunkan Empat Fase yaitu : Perencanaan, Tindakan, Observasi, dan Refleksi. Keempat fase tersebut merupakan suatu siklus dalam sebuah penelitian tindakan kelas.

Subjek dari penelitian ini adalah peserta didik kelas XI MA Nurul Huda Sukaraja yang berjumlah 30 peserta didik, terdiri dari 20 peserta didik perempuan dan 10 peserta didik laki-laki. Metode pengumpulan data adalah cara atau langkah-langkah yang dilakukan peneliti untuk memperoleh data penelitian. Metode pengumpulan data dalam penelitian ini adalah observasi dan tes. 
Observasi (observation) atau pengamatan merupakan suatu teknik atau cara mengumpulkan data dengan jalan mengadakan pengamatan terhadap kegiatan yang sedang berlangsung, kegiatan tersebut bisa berkenaan dengan cara guru mengajar, peserta didik belajar, kepala sekolah yang sedang memberikan pengarahan dan lain-lain (Sukmadinata, 2011:220). Sedangkan menurut Sutrisno Hadi (1986) observasi merupakan suatu proses yang kompleks, suatu proses yang tersusun dari berbagai proses biologis dan psikologis. Metode observasi dalam penelitian ini dilakukan untuk mengetahui perkembangan proses pembelajaran yang dilakukan oleh peserta didik dan guru sejak sebelum pelaksanaan tindakan sampai akhir tindakan. Hasil observasi dianalisis untuk mengetahui berbagai perkembangan yang ada dan dicari solusinya terhadap kelemahan tersebut.

Pengumpulan data dalam penelitian ini dilakukan dengan menggunakan tes. Menurut Arikunto (2010:193) tes merupakan serentetan pertanyaan atau latihan serta alat lain yang digunakan untuk mengukur keterampilan peserta didik, pengetahuan intelegensi, kemampuan atau bakat yang dimiliki oleh individu atau kelompok. Teknik ini peneliti gunakan untuk menganalisis sejauh mana pemahaman peserta didik terhadap materi pelajaran. Tes yang digunakan dalam penelitian ini adalah tes yang dibuat peneliti terkait dengan materi pembelajaran. Tes disusun sebanyak 4 soal dengan bentuk essay. Tes diberikan kepada seluruh peserta didik yang menjadi sampel penelitian.

Muslich (2011:52) mengatakan teknik analisis data dalam penelitian tindakan kelas dilakukan melalui 3 tahap, yaitu reduksi data, paparan data, dan penyimpulan. Adapun analisis data observasi menggunakan rumus sebagai berikut:

$$
P=\frac{F}{N} x 100 \%
$$

Keterangan:

$\mathrm{F}=$ Skor total aktifitas.

$\mathrm{N}=$ Jumlah skor maksimal.

$\mathrm{P}=$ Angka persentase aktifitas ( Sudijono: 2010)

Hasil tes peserta didik dianalisis untuk melihat daya serap peserta didik setelah mengikuti pembelajaran Ekonomi menggunakan model pembelajaran 
Artikulasi. Langkah-langkah yang digunakan dalam menganalisis data tes adalah memberi skor patokan yang telah ditentukan kemudian memberi nilai pada lembar jawaban yang diperoleh setiap peserta didik dengan menggunakan rumus sebagai berikut:

$$
N \frac{X}{Y} x 100 \%
$$

$$
\begin{aligned}
& \text { Keterangan: } \\
& \mathrm{N}=\text { Nilai } \\
& \mathrm{X}=\text { Skor yang diperoleh } \\
& \mathrm{Y}=\text { Skor maksimal }
\end{aligned}
$$

Selanjutnya untuk menafsirkan hasil perhitungan dengan prosentase, peneliti menggunakan rumus sebagai berikut:

Tabel 1 Taraf Hasil Belajar

\begin{tabular}{cccc}
\hline $\begin{array}{c}\text { Taraf Penguasaan atau } \\
\text { Kemampuan (\%) }\end{array}$ & Kualifikasi & $\begin{array}{c}\text { Nilai } \\
\text { Angka }\end{array}$ & Keterangan \\
\hline $70 \%-100 \%$ & Baik & $70-100$ & Berhasil \\
\hline $39 \%-69 \%$ & Kurang & $30-69$ & Tidak berhasil \\
\hline
\end{tabular}

Target keberhasilan penelitian tindakan kelas ini adalah:

1. $85 \%$ peserta didik semangat dalam kegiatan pembelajaran

2. $90 \%$ peserta didik mendengarkan penjelasan guru

3. $90 \%$ peserta didik aktif dalam proses pembelajaran

4. $85 \%$ peserta didik aktif berwawancara dengan teman

5. $80 \%$ peserta didik aktif menyampaikan hasil wawancara

6. $95 \%$ nilai ulangan harian peserta didik mencapai kriteria ketuntasan minimal $(\mathrm{KKM}) \geq 73$

Selanjutnya peneliti mempunyai target observasi guru sebesar $95 \%$ untuk ketuntasan hasil belajar sebesar 95\% dan observasi peserta didik 95\%.

\section{HASIL DAN PEMBAHASAN}

Penelitian ini dilakukan melalui model artikulasi dengan tujuan meningkatkan hasil belajar peserta didik pada mata pelajaran Ekonomi. Dalam 
pembelajaran ini ada beberapa kegiatan yang harus dilakukan oleh guru dan peserta didik yang sesuai dengan langkah-langkah model artikulasi (Huda, 2014: 268). Pembelajaran diterapkan dengan menggunakan model pembelajaran Artikulasi. Menurut Suprijono (2009: 126) Model pembelajaran ini merupakan model yang proses pembelajarannya peserta didik diminta untuk menyampaikan materi yang didapatkan dari guru kepada pasangannya secara bergiliran, didalam pasangan tersebut terdapat penyampai dan pendengar.

Berdasarkan data pengamatan kegiatan guru pada siklus I bahwa dari 51 aspek yang dinilai masih terdapat beberapa aspek yang mendapat kriteria kurang. Aspek-aspek itu antara lain aspek memberi apersepsi mata pelajaran dan mengumpulkan hasil diskusi masing-masing kelompok.

Kekurangan ini kemudian diperbaiki pada siklus II, guru memperbaiki cara memberi apersepsi pada mata pelajaran dan mengumpulkan hasil diskusi masing-masing kelompok. Hasil dari perlakuan untuk kegiatan guru dalam pembelajaran ini adalah meningkatnya kegiatan guru pada siklus I sebesar $92,16 \%$, pada siklus II kegiatan guru meningkat menjadi 100\%.

Lembar pengamatan aktivitas peserta didik terdapat 5 aspek yang dinilai masih terdapat beberapa aspek yang mendapat kriteria kurang. Aspek-aspek itu antara lain aspek semangat dalam kegiatan pembelajaran, mendengarkan penjelasan guru, dan aktif dalam proses pembelajaran. Kekurangan ini kemudian diperbaiki pada siklus II, guru memperbaiki cara menjelaskan materi dengan menggunakan contoh-contoh, guru menggunakan model pembelajaran artikulasi, dan guru membentuk kelompok berpasangan dua orang (Huda, 2014: 268). Hasil dari perlakuan ini adalah meningkatnya aktivitas peserta didik dari nilai rata-rata pada siklus I $87,34 \%$, setelah dilanjutkan pada pada siklus II meningkat menjadi 97,58\%.

Belum optimalnya kegiatan pembelajaran yang dilakukan oleh guru maupun aktivitas peserta didik selama kegiatan pembelajaran berlangsung memberi dampak pada penguasaan materi sehingga kurang baik terhadap hasil belajar peserta didik. Pada evaluasi siklus I tes yang digunakan terdiri atas 4 butir soal essay terlihat pada (lampiran 10) yang bertujuan untuk menguji pemahaman peserta didik. Dari 30 peserta didik yang diberikan tes dimana 20 orang atau 66,67\% yang tuntas dan 10 orang atau 33,33\% mendapat nilai dibawah standar ketuntasan 73. Presentase ini menunjukkan belum adanya peningkatan karena hasilnya masih rendah. Dalam pembelajaran model 
artikulasi pada siklus I peserta didik kurang mendengarkan penjelasan guru. Kurangnya peserta didik memahami materi, pada siklus I diperbaiki pada siklus II yaitu dengan cara guru menggunakan model pembelajaran artikulasi.

Peningkatan kegiatan guru dan peserta didik dalam pembelajaran berdampak pula pada peningkatan pemahaman peserta didik yang dapat diketahui dari hasil tes evaluasi siklus II. Pada evaluasi siklus II tes yang digunakan terdiri atas 4 butir soal essay terlihat pada (lampiran 15), berdasarkan hasil tes evaluasi siklus II dapat diketahui bahwa dari 30 peserta didik yang diberikan tes dimana 29 orang atau 96,7\% yang tuntas dan 1 orang atau 3,3\% mendapat nilai dibawah standar ketuntasan 73 . Hasil belajar pada siklus II telah mengalami peningkatan sebesar $30,03 \%$ dari $66,67 \%$ yang tuntas pada siklus I menjadi $96,7 \%$ yang tuntas pada siklus II.

Dengan terjadinya peningkatan hasil belajar peserta didik berarti hipotesis penelitian yakni "Jika menggunakan model pembelajaran artikulasi maka hasil belajar peserta didik pada mata pelajaran Ekonomi dapat meningkat". Terbukti dengan penelitian ini.

Berdasarkan penjelasan di atas maka dapat peneliti kemukakan salah satu upaya untuk meningkatkan hasil belajar peserta didik pada mata pelajaran Ekonomi kelas XI di MA Nurul Huda Sukaraja yaitu dengan menggunakan model pembelajarn artikulasi. Hal ini dikarenakan pembelajaran dengan menggunakan model ini lebih menuntut peserta didik aktif dan menarik perhatian dalam proses pembelajaran sehingga membantu peserta didik dalam memahami materi yang diajarkan oleh guru serta dapat meningkatkan hasil belajar peserta didik tersebut.

\section{SIMPULAN}

Berdasarkan hasil penelitian tindakan kelas melalui penerapan model pembelajaran Artikulasi pada kelas XI MA Nurul Huda Sukaraja dapat disimpulkan bahwa penerapan model artikulasi dalam pembelajaran Ekonomi dapat meningkatkan hasil belajar peserta didik. Hal ini dibuktikan dengan:

Penerapan model pembelajaran artikulasi pada pembelajaran Ekonomi di kelas XI MA Nurul Huda Sukaraja memperoleh hasil pengamatan terhadap aktivitas peserta didik terhadap aktivitas peserta didik dalam proses pembelajaran pada pra siklus peserta didik yang semangat dalam kegiatan 
pembelajaran sebanyak $65,6 \%, 62,2 \%$ peserta didik mendengarkan penjelasan guru, $62,2 \%$ peserta didik yang aktif dalam proses pembelajaran, $64,4 \%$ peserta didik yang aktif berwawancara dengan teman, dan 58,9\% peserta didik aktif menyampaikan hasil wawancara, pada siklus I meningkat menjadi $87,78 \%$ peserta didik yang semangat dalam kegiatan pembelajaran, $86,7 \%$ peserta didik mendengarkan penjelasan guru, $91,1 \%$ peserta didik yang aktif dalam proses pembelajaran, $86,7 \%$ peserta didik yang aktif berwawancara dengan teman, $84,4 \%$ peserta didik aktif menyampaikan hasil wawancara dan pada siklus II juga meningkat menjadi sebanyak $100 \%$ peserta didik yang semangat dalam kegiatan pembelajaran, $100 \%$ peserta didik mendengarkan penjelasan guru, $97,8 \%$ peserta didik yang aktif dalam proses pembelajaran, 95,6\% peserta didik yang aktif berwawancara dengan teman, dan $95,6 \%$ peserta didik aktif menyampaikan hasil wawancara.

Hasil belajar peserta didik kelas XI MA Nurul Huda Sukaraja dalam pembelajaran Ekonomi setelah dilakukan tindakan diperoleh rata-rata nilai hasil belajar siklus I sebesar 73,16 dan pada siklus II rata-rata nilai hasil belajar peserta didik mampu mencapai 89,66.

Penerapan model pembelajaran artikulasi dapat meningkatkan hasil belajar peserta didik kelas XI MA Nurul Huda Sukaraja. Hal ini dapat dilihat dari rata-rata hasil belajar peserta didik sebelum adanya tindakan dilakukan (pra siklus) adalah sebesar $68,66 \%$, setelah dilakukan tindakan perbaikan pada siklus I sebesar $73,16 \%$, dan pada siklus II meningkat sebesar $89,66 \%$. Jadi terlihat adanya peningkatan hasil belajar peserta didik pada pra siklus ke siklus I sebanyak 26,67, dari siklus I ke siklus II sebanyak 30,03\%.

\section{SARAN}

Berdasarkan hasil penelitian, peneliti menyampaikan saran sebagai berikut:

1. Untuk meningkatkan hasil belajar peserta didik pada pembelajaran Ekonomi sebaiknya guru menggunakan model pembelajaran artikulasi dalam kegiatan pembelajaran agar semua peserta didik dapat berperan aktif. Selain itu dalam melakukan kegiatan pembelajaran di kelas guru hendaknya memperhatikan pengelolaan waktu agar sesuai dengan prosedur rencana tindakan yang telah ditetapkan. 
2. Peserta didik hendaknya lebih giat lagi dalam belajar, serta menerima model pembelajaran yang diberikan oleh guru untuk meningkatkan hasil belajar peserta didik.

3. Sekolah hendaknya memberikan kesempatan kepada guru agar dapat berinovasi dan berkreasi dalam kegiatan pembelajaran. Sebagai contoh, dengan menggunakan model pembelajaran artikulasi, guru dapat memberikan kontribusi untuk meningkatkan kualitas sekolah.

4. Bagi para peneliti hendaknya mampu menemukan dan mengembangkan model-model pembelajaran yang lebih bervariasi yang dapat meningkatkan kualitas pembelajaran di kelas.

\section{UCAPAN TERIMAKASIH}

Ucapan terimakasih ditujukan kepada Ketua STKIP Nurul Huda, Ketua LPPM STKIP Nurul Huda, Tim Jurnal Utility STKIP Nurul Huda, Kepala SMP Negeri 2 Belitang Mulya dan segenap dewan dosen dan staf STKIP Nurul Huda.

\section{REFERENSI}

Agustini, E., dkk. (2014). Pengaruh Model Pembelajaran Artikulasi Berbantuan Media Kartu Gambar Untuk Meningkatkan Kemampuan Bahasa Anak TK Pada Tahun 2014.

Arikunto, S. (2006). Prosedur Penelitian; Suatu Pendekatan Praktik. Jakarta: Rineka Cipta.

Arikunto, S. (2010). Prosedur Penelitian. Jakarta: Rineka Cipta.

BSNP. (2007). Pedoman Penilaian Hasil Belajar di Sekolah Dasar. Jakarta: Depatemen Pendidikan Nasional Direktorat Jendral Mandikdasmen Direktorat Pembinaan TK dan SD.

Desriana, G, dkk. (2012). Pengaruh Penggunaan Model Pembelajaran Artikulasi Terhadap Hasil Belajar Siswa Pkn Kelas VII SMP IT AlBayinah Pekanbaru.

Hamalik, O. (2007). Dasar-dasar Pengembangan Kurikulum.Bandung: Remaja Rosdakarya 
Huda, M. (2013). Model-model pengajaran dan pembelajaran: Yogyakarta: Pustaka Belajar.

Junianto, A. (2014). Peningkatan Aktivitas dan Hasil Belajar IPS Melalui Model Artikulasi dan Media Power Point Pada Tahun 2014. Jurnal FKIP.

Khotijah, S. (2014). Penerapan Model Pembelajaran Artikulasi Dalam Upaya Meningkatkan Hasil Belajar Siswa Pada Materi Atmosfer. Jurnal Pendidikan Fisika. 4-16.

Kunandar. (2010). Langkah Mudah Penelitian Tindakan Kelas. Jakarta: Indeks.

Leluhur, W. (2008). Peningkatan Prestasi Belajar Siswa melalui Cooperatif Learning Model Artikulasi dan Evaluasi Bentuk MultipleChoice Mata Pelajaran IPS Pada Siswa Kelas VIII C SMP Negeri I Licin Semester II Pelajaran 2008/2009. Jurnal Ilmiah Progressif.

Lisnawan, R. (2015). Peningkatan Pembelajaran Materi Proklamasi Kemerdekaan Indonesia Melalui Model Artikulasi Pada Siswa Kelas V Sekolah Dasar Negeri 2 Somawangi Banjarnegara. Skripsi. Semarang: Universitas Negeri Semarang.

Pese, H. dkk. (2012). Penerapan Model Pembelajaran Kooperatif Tipe Artikulasi Unruk Meningkatkan Hasil Belajar Fisika Siswa Pada Kelas VIIIB SMP Negeri2 Marawola. Jurnal Pendidikan Fisika Tadulako. 1.1: 42-47.

Purwanto. (2009). Evaluasi Hasil Belajar. Yogyakarta: Pustaka Belajar.

Sudijono, A. (2010). Pengantar Statistik Pendidikan. Jakarta: Raja Grafindo Persada.

Sudjana, N. (2009). Penilaian Hasil Proses Belajar Mengajar. Bandung: Remaja Rosdakarya.

Slameto. (2003). Belajar dan Faktor-Faktor yang Mempengaruhinya. Jakarta: Rineka Cipta.

Team STKIP Nurul Huda. (2008). Pedoman Akademik STKIP Nurul Huda Sukaraja. Sukaraja: STKIP Nurul Huda 
Peningkatan Hasil Belajar Peserta Didik pada Mata Pelajaran Ekonomi Melalui Model Pembelajaran Artikulasi Kelas XI di MA Nurul Huda Sukaraja

Trianto. (2009). Mendesain Model-model Pembelajaran Inovatif Progresif. Jakarta: Kencana. 